\title{
TYPHUS AND ITS CONTROL IN RUSSIA, $1870-1940$
}

\author{
by
}

\section{K. DAVID PATTERSON *}

Typhus was a major health problem in late nineteenth- and early twentieth-century Russia. Closely linked with poverty and overcrowded housing, this louse-borne disease was endemic in both rural and urban areas, with scattered cases and small outbreaks occurring every year, mostly in the winter and early spring. Great epidemics flared up whenever war or famine produced hardship and massive population movements. The worst typhus epidemics took place late in World War I and in the years of civil war following the Bolshevik Revolution. Typhus claimed some 2 to 3 million lives from 1918 to 1922. Incidence rates fell dramatically in the later 1920s and the disease had ceased to be a significant cause of death by 1940 . There was, however, a sharp flare-up in the early 1930s, undoubtedly associated with the dislocations caused by Stalin's industrialization and collectivization drives, and the ensuing famines.

Typhus is an acute febrile disease caused by a rickettsial organism, Rickettsia prowazeki. The pathogen is transmitted by the body louse Pediculus humanus. As the insect lives in the clothes of its host, the Russian term platyanaya vosh', clothes louse, is more accurate than the English term. Lice attach to their host for blood meals and acquire rickettsias from typhus patients. They transmit infection to other hosts if their pathogen-rich faeces are inoculated through abrasions in the skin, as, for example, when a louse bite is scratched. Symptoms include high fever, prostration, mental confusion, and a characteristic rash. People of all ages are susceptible to typhus, although children tend to have milder cases. Differential exposure to infected lice often produces higher attack rates in males of military or working age than in females, children, or the elderly. Case mortality rates range from 5 to 40 per cent and even higher. The role of lice as vectors was proved in 1909 by Charles Nicolle. The pathogen was discovered in 1916, but questions about its role were not finally resolved for several more years. ${ }^{1}$

\footnotetext{
* Prof. K. David Patterson, Graduate School, University of North Carolina at Charlotte, Charlotte, NC, 28223, USA.

Research for this article was supported in part by grants from the Foundation of the University of North Carolina and from the State of North Carolina and from the University of Illinois Swummer Research Laboratory on Russia and Eastern Europe. It is a pleasure to acknowledge the capable assistance of Barbara Lisenby and her staff in the inter-library loan department of the UNC at Charlotte library. A version of this article was presented as the Edward and Amalie Kass Lecture at the Wellcome Institute for the History of Medicine, London, on 29 October 1992.

' For information on typhus and its vector, see Robert F. Harwood and Maurice T. James, Entomology in human and animal health, 7th ed., New York, Macmillan, 1979, pp. 131-3; John C. Snyder, in Frank L. Horsfall and Igor Tamm (eds), Viral and rickettsial infections of man, Philadelphia, Ronald, 1965, pp. 1059-76; David T. Smith and Norman F. Conant (eds), Zinsser microbiology, 12th ed., New York, Appleton-Century-Crofts, 1960 , pp. 574-81; Richard J. Duma, 'Typhus fever', in Paul Hoeprich and M. Colin Jordan (eds), Infectious diseases, Philadelphia, J. B. Lippincott, 1989, pp. 970-6; Victoria A. Harden, 'Typhus, epidemic' in Kenneth F. Kiple (ed.), The Cambridge world history of human diseases, Cambridge University Press, 1993, pp. 1080-4.
} 


\section{K. David Patterson}

Louse-borne typhus is probably a relatively new disease. Infection is fatal to the louse, suggesting a short evolutionary relationship between pathogen and vector. ${ }^{2}$ Typhus apparently swept war-torn southern Spain in the late 1400s and was certainly active in Italy, Hungary, and other areas during the sixteenth century. Girolamo Fracastoro wrote the classic description in 1546. War helped spread typhus throughout Europe during the seventeenth century, and the disease probably became established in Russia at this time. Typhus was widely associated with crowding, prisons, war, and famine in this and later centuries, with especially notable epidemics during Napoleon's retreat from Moscow in 1812-13 and during the Irish potato famine of the late $1840 \mathrm{~s}^{3}{ }^{3}$ The association between famine and typhus is not nutritional, but indirect. The threat of starvation forces destitute people to wander about in search of food, spreading infected lice to new victims. In addition, people weakened by hunger are less able to keep themselves clean, especially in winter or when driven from their homes. ${ }^{4}$

The early history of typhus in Russia is poorly documented. Descriptions of outbreaks of "spotted fever" or "putrid fever", which seems to have been typhus, date from the sixteenth and seventeenth centuries. Typhus was probably epidemic during the "Time of Troubles" in the early 1600s. A number of typhus epidemics took place in the eighteenth century, especially in the army, and the disease was familiar to Moscow physicians at the time of the plague epidemic of $1771 .^{5}$ Prior to the Napoleonic wars, there do not seem to have been many geographically widespread typhus epidemics among the civilian population. Outbreaks were apparently limited to small foci by Russia's vast distances, sparse population, and wretched transportation. On the other hand, lice were a common pest. For example, the Marquis de Custine was tormented by lice, bedbugs, and fleas during his travels in Russia in 1839. "In Russian inns," he wrote, "not excepting those of the best description, all wooden furniture with stuffed cushions are so many hives where vermin swarm and multiply." While visiting a famous monastery, he "passed the night making war with an army of vermin, black and brown, of every form, and, I believe, every species. The death of one of them seemed to draw on me the vengeance of the whole race, who rushed upon the place where the blood had flowed, and drove me almost to desperation." 6 Conditions in crowded peasant huts could not have been much better, but the traditional Russian bath may have helped to control louse populations. ${ }^{7}$

\footnotetext{
${ }^{2}$ Hans Zinsser, Rats, lice and history, repr. Boston, Bantam, 1971 (1st ed. 1934), pp. 178-80; Melinda S. Meade, John W. Florin, and Wilbert M. Gesler, Medical geography, New York, Guilford, 1988, p. 67.

${ }^{3}$ Zinsser, op. cit., note 2 above, pp. 184-9; Pierre Saraudy, 'Les épidémies de typhus exanthématique et le rôle du pou dans l'histoire', thesis for Doctorat en Médecine, University of Paris, 1930, pp. 10-11, 29-43; August Hirsch, Handbook of geographical and historical pathology, 3 vols, London, New Sydenham Society, 1883-86, vol. 1, pp. 545-54; W. P. MacArthur, 'The medical history of the famine', in R. D. Edwards and T. D. Williams (eds), The great famine, Dublin, Russell and Russell, 1956, pp. 265-304; Charles-Edward Amory Winslow, The conquest of infectious disease: a chapter in the history of ideas, repr., Madison, Wisconsin University Press, 1980 (1st ed. 1943), p. 138.

${ }^{4}$ John D. Post, Food shortage, climatic variability, and epidemic disease in early modern Europe: the mortality peak in the early 1740s, Ithaca, Cornell University Press, 1985, pp. 227-32, 271-2; John Walter and Roger Schofield, 'Famine, disease and crisis mortality in early modern society', in Walter and Schofield (eds), Famine, disease and the social order in early modern society, Cambridge University Press, 1989, p. 53.

5 John T. Alexander, Bubonic plague in early modern Russia: public health \& urban disaster, Baltimore, Johns Hopkins University Press, 1980, pp, 11-12, 16-17, 143-4.

${ }^{6}$ Marquis de Custine, Empire of the Czar: a journey through eternal Russia, New York, Doubleday, 1989, pp. $365,459-60$.

${ }^{7}$ K. G. Vasil'ev and A. E. Segal, Istoriya epidemii v Rossii (Materialy i ocherki), Moscow, Medgiz, 1960, pp. 185-94.
} 
Typhus spread rapidly among Russian soldiers and civilians, as well as among the troops of the invading French and their allies during 1812 and 1813. From that time on, scattered epidemics were recorded almost annually in towns, garrisons, and rural areas. ${ }^{8}$ There were serious epidemics engulfing whole provinces in the late 1830 s and during the poor harvest years of 1845-46. Similarly, the Crimean War stimulated major epidemics which spread northward over most of European Russia in the 1850s; the Russo-Turkish War of 1877-78 did the same. ${ }^{9}$ A quarantine prevented infected troops from spreading typhus to Odessa in 1878 , but this was a rare success. ${ }^{10}$ Moscow and St Petersburg almost certainly had become endemic foci by at least the early 1860s; the same was most likely true for other major cities. $^{11}$

The problem of retrospective diagnosis confounds the study of typhus in Russia and elsewhere until well into the nineteenth century. Studies by French and American doctors in the 1830s distinguished typhus from typhoid or "abdominal typhus", and by the 1840s there was a growing international recognition that the diseases were distinct. ${ }^{12}$ Russian physicians fully accepted this distinction by the 1860 s, especially after the studies of S.P. Botkin. ${ }^{13}$ By then, Russian observers also distinguished typhus from another louse-borne disease, relapsing fever. ${ }^{14}$ Thus, while problems of diagnosis remained and statistical tables sometimes continued to list relapsing fever as a variant of typhus and to include significant numbers of cases under rubrics like "typhus-undifferentiated" well into the $1890 \mathrm{~s}$, data on the disease became much more reliable in the late $1860 \mathrm{~s}$, and, thanks to the growth of the medical profession and the remarkable development of rural medicine after the zemstvo reforms, more abundant as well.

It is clear, for example, that St Petersburg suffered from concurrent epidemics of typhus, typhoid, and relapsing fever in 1864-65. At least 1,198 deaths in city hospitals were attributed to typhus and the real toll may have been much higher. ${ }^{15}$ The new capital suffered another severe epidemic in 1877-78 in the aftermath of the Russo-Turkish war; 1,719 fatal

\footnotetext{
${ }^{8}$ Vasil'ev and Segal, op. cit., note 7 above, pp. 315-18; Hirsch, op. cit., note 3 above, pp. 558-9; G. M. Vaindrakh, Podvigi russkikh vrachei, Moscow, Akademiya Nauka SSSR, 1959, p. 70.

${ }^{9}$ Vasil'ev and Segal, op. cit., note 7 above, pp, 317-21; Hirsch, op. cit., note 3 above, pp. 558-9.

${ }^{10}$ Patricia Herlihy, Odessa, a history 1794-1914, Cambridge, Mass., Harvard University Press, 1986, p. 235.

"Vasil'ev and Segal, op. cit., note 7 above, p. 320; John Millar, 'Notes on the recent epidemic in St Petersburg', Edinburgh Med. J., 1864, 11: 225-31; Bulletin de la société royale de médicine de Belgique, 'De la maladie qui règne actuellement en Saint-Petersbourg', 1865, 2nd sér., pp. 259-79; Patricia Herlihy, 'Death in Odessa: a study of population movements in a nineteenth-century city', J. urban Hist., 1978, 4: 417-42, on p. 427. Typhus is cited in Riga in Anders Henriksson, 'Riga', in Michael F. Hamm (ed.), The city in late imperial Russia, Bloomington, Indiana University Press, 1986, pp. 177-208, on pp. 185-6. The disease undoubtedly did occur there, but the references cited mistake typhus for water-borne typhoid fever.

${ }^{12}$ Erwin H. Ackerknecht, Medicine at the Paris hospital, 1794-1848, Baltimore, Johns Hopkins University Press, 1967, pp. 103-4; Leonard G. Wilson, 'Fevers and science in early nineteenth-century medicine', J. Hist. Med. allied Sci., 1978, 33: 386-406; Dale C. Smith, 'Gerhard's distinction between typhoid and typhus and its reception in America, 1833-1860', Bull. Hist. Med., 1980, 54: 368-85.

${ }^{13}$ Vasil'ev and Segal, op. cit., note 7 above, pp. 314-15.

${ }^{14}$ Bulletin de la société royale, 'De la maladie', op. cit., note 11 above, pp. 267-8; A. I. Metelkin, 'Iz istorii izucheniya parazitarnykh tifov v Rossii (k 75-letiyu geroicheskogo opyta O. O. Mochutkovskogo)', Zhurnal mikrobiologii, epidemiologii, i immunobiologii, 1951, 22(6): 72-7, p. 72; Metelkin, Supplement, Sketch II, 'Iz istorii bor'by s purazitarnymi tifami v Rossii', in Vasil'ev and Segal, op. cit., note 7 above, pp. 372-3. The studies of E. S. Govorliv in 1857 and V. T. Pokrovskii in the $1860 \mathrm{~s}$ were especially important.

${ }^{15}$ Millar, op. cit.; note 11 above, p. 226; Bulletin de la société royale, 'De la maladie', op. cit., note 11 above, pp. 277-8.
} 
Figure 1: Typhus cases in St Petersburg, 1864-1896.

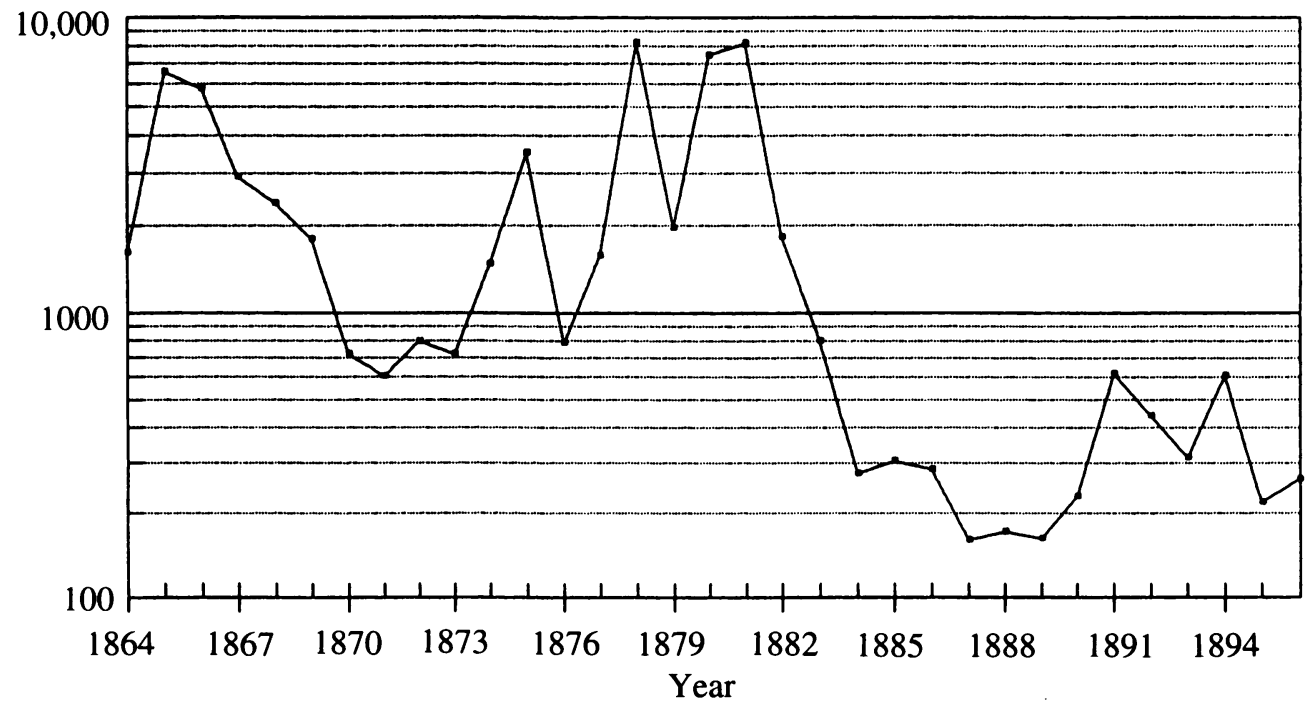

Typhus cases

(Sources: Golynts, p. 1151, and Orlov, p. 18, see note 18.)

cases were reported, with 1,329 male and 390 female victims. Seventy-five of the dead were doctors, nurses, or hospital attendants. ${ }^{16}$ Indeed, typhus always was especially dangerous for medical personnel and researchers, in Russia and elsewhere. During the 1890s 60 per cent of all deaths among zemstvo physicians were caused by typhus and other infectious diseases. ${ }^{17}$

Typhus, epidemic annually in St Petersburg for the rest of the century, was carefully studied by local physicians, notably N. Ivanov, L. I. Golynts, and P. P. Orlov. Their publications, sophisticated statistical studies based on hospital and registration data, city censuses, and personal observations, provide a detailed picture of typhus in an urban Russian environment which can only be sketched here. Figure 1 shows typhus reports from 1864 to 1896 ; incidence ranged from 160 to 8,215 cases a year. The disease was also highly seasonal. Data aggregated by month for a ten-year span, shown in Figure 2, indicate that typhus in St Petersburg and Moscow was primarily a winter-spring disease, reflecting indoor crowding, fewer opportunities to bathe or wash clothing and bedding, and seasonal migration patterns. This seasonality was observed throughout the country. Case mortality rates were generally in the 10 to 15 per cent range; in St Petersburg 6,980 deaths were registered from 1870 to 1887 and 264 in the quieter period from 1888 to 1896 . $^{18}$ In 1878 ,

${ }^{16}$ P. Zagorski, 'Uebersicht der Typhus-Sterblichkeit während der Epidemie von 1877/78 in St. Petersburg', Medicinische Wochenschrift, 1879, 7: 49-51.

${ }^{17}$ Nancy Mandelker Frieden, Russian physicians in an era of reform and revolution, 1856-1905, Princeton University Press, 1981, p. 222.

${ }^{18}$ L. I. Golynts, 'Smertnost' ot sypnogo tifa po dannym Peterburga (s 1870 po 1887 gg.)', Vrach, 1890, no. 51: 1151-2 and no. 52: 1173-6, on p. 1151; P. P. Orlov, Zabolevaemost' $i$ smertnost' ot sypnogo tifa v S.-Peterburg s 1887 po 1896 god, St Petersburg, I. I. Soikin, 1897, p. 19. 
Figure 2: Average monthly typhus cases, St Petersburg, 1887-96; Moscow, 1883-1908.



St Petersburg Moscow

(Sources: Orlov, p. 27, see note 18; P. I. Kurkin, Sanitarno Statisticheskii tablitsy, Moscow, Pirigov Society, 1910, p. 138.)

the worst year, the typhus death rate reached 190/100,000 and the disease accounted for 5.3 per cent of all deaths recorded in the city. ${ }^{19}$ Rural-urban migration patterns meant that in St Petersburg, as in other cities, young and middle-aged adults, mostly male, were most vulnerable to infection and death. Figures 3 and 4 illustrate these differences.

Investigators were able to link typhus closely with poverty and crowding; peasants who migrated to St Petersburg after the harvest to seek work during the winter and early spring were the most vulnerable. The migrants, predominantly males in their late teens to early forties, lived close together in barracks-like dosshouses or rented "corners" of rooms. Their miserable living conditions ensured they were disproportionately represented in the city's morbidity and mortality returns. Natives and long-time residents of the capital had much lower rates, reflecting greater prosperity and, in many cases, a degree of acquired immunity, perhaps from mild childhood cases. ${ }^{20}$

Orlov was able to indentify foci which flared up year after year in small areas and even in individual houses. ${ }^{21}$ It is now known that viable rickettsiae can persist for months in the dust from dried rat faeces. 22 "Typhus houses" could also persist through relapses of Brill's disease, a mild form of typhus occurring years after recovery from initial attack. ${ }^{23}$

${ }^{19}$ Golynts, op. cit., note 18 above, p. 1151.

${ }^{20} \mathrm{~N}$. Ivanov, 'Zabolevaemost' sypnym tyfom pod vliyaniem vozrasta, pola i prodolozhitel'nosti $v$ S.Peterburge', Voennomeditsinskii zhurnal, chast' 157, neofitsial'naya chast', 1886, pp. 77-100, 189-204, 263-94, on pp. 99, 190-8; Golynts, op. cit., note 18 above, pp. 1151, 1173-5; Orlov, op. cit., note 18 above, pp. 42-84.

${ }^{21}$ Orlov, op. cit., note 18 above, pp. 68-70.

22 Harwood and James, op. cit., note 1 above, pp. 131-3. In such cases, rickettsias enter the body through the ocular or oral mucosa. Anne Hardy presents evidence for the existence of similar "typhus houses" in London in the 1860s in 'Urban famine or urban crisis: typhus in the Victorian city', Med. Hist., 1988; 32: 401-25, on p. 406.

${ }^{2.3}$ Ernest Jawetz, Joseph L. Melnick, and Edward A. Adelberg (eds), Review of medical microbiology, 16th ed., Los Altos, Lange, 1984, pp. 271-4; Smith and Conant, op. cit., note 1 above, pp. 574-5, 579. 


\section{K. David Patterson}

Figure 3: Typhus deaths in St Petersburg, Nov. 1877-Aug. 1878, by age group.



(Source: Zagorski, p. 50, see note 16.)

Figure 4: Typhus cases by gender, St Petersburg, 1887-1896.



Male

(Source: Orlov, p. 37, see note 18.) 
Thus by the third quarter of the nineteenth century, Russian doctors, like their western European counterparts, had acquired a great deal of empirical knowledge about the epidemiology of typhus. The disease was closely linked to crowding, filth, and poverty. It seemed to spread by close contact with victims or their clothes and bedding. Doctors and others who cared for the sick were at special risk, as were laundresses. On the other hand, bath-house attendants rarely contracted typhus. ${ }^{24}$ In a contagious disease hospital set up in an old St Petersburg fire station in early 1880, 19 out of 100 nurses and other attendants contracted typhus, as did 2 of the 6 attending doctors. Two laundry workers, who had no direct contact with patients, also got the disease. ${ }^{25}$

Preventive measures included prompt removal of the sick to hospitals and disinfection of their persons, clothes, and premises. ${ }^{26}$ In major cities authorities attempted to control typhus by inspecting and disinfecting dosshouses, with at least some success. In Odessa, such measures were credited with reducing typhus rates ten-fold between 1875 and $1895 .{ }^{27}$ Health authorities in Tula fought an 1892 epidemic by hiring extra doctors, isolating the sick in hospitals, and regularly inspecting municipal and private lodging establishments for patients and unsanitary conditions. Unaware of the role of lice, they attacked filth in all forms, from bedding to walls, floors, and overflowing cesspits. Clothes and linens were

Figure 5: Typhus cases in Russia/USSR, 1877-1936 (log. scale).

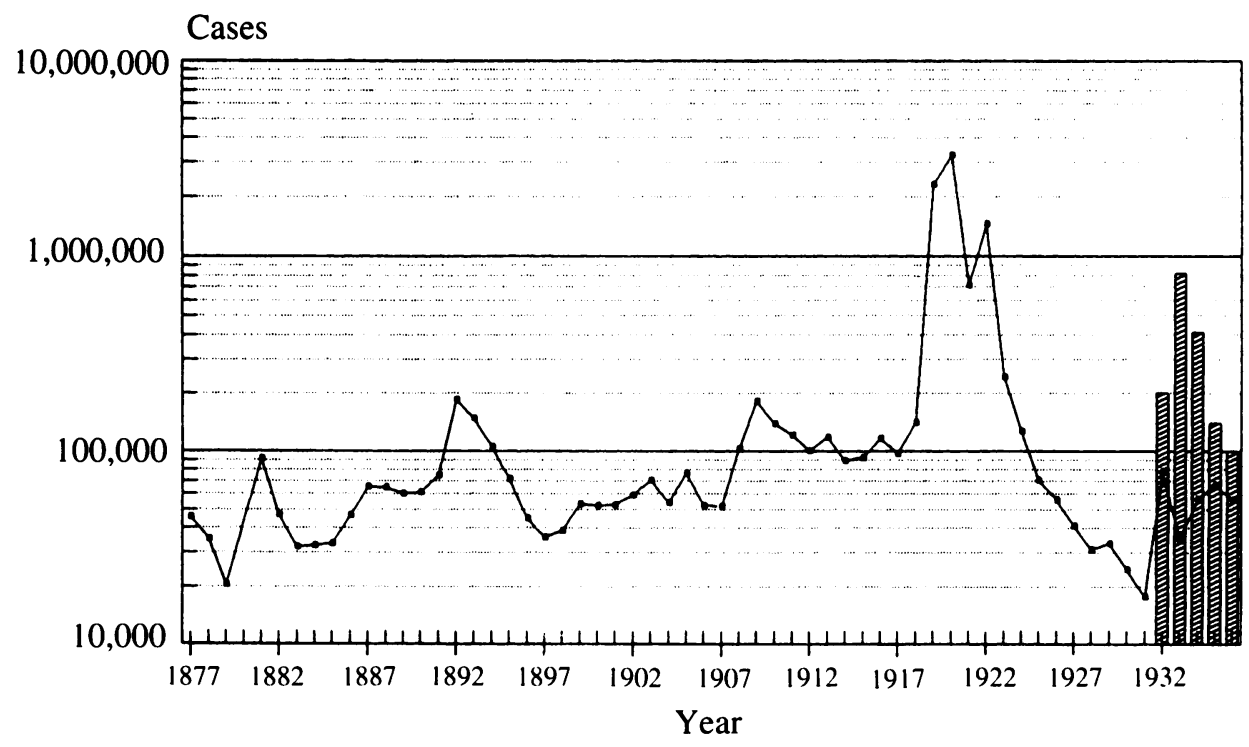

-.- Log. number of cases Baroyan data

(Sources: League of Nations Health Organization, Amnual epidemiological reports; Pletnev, see note 79; Vasil'ev and Segal, pp. 323-4, see note 7; Baroyan, p. 56, see note 98.)

${ }^{24}$ Orlov, op. cit., note 18 above, pp. 86-90.

25 Viryuzhskii, 'K istorii tifoznoi epidemii v S. Peterburge', Meditsinskii vestnik, 1880, 20: 105-7, on p. 106.

${ }^{26}$ Orlov, op. cit., note 18 above, p. 105; M. M. Kholevinskii, 'Ob epidemii sypnogo tifa v g. Tulag', Sanitarnoe delo, 1892, nos. 27-28, pp. 265-9.

${ }^{27}$ Patricia Herlihy, op. cit., note 11 above, p. 427; Kholevinskii, op. cit., note 26 above, pp. 266-8. 


\section{K. David Patterson}

disinfected with carbolic acid solutions in specially constructed chambers. ${ }^{28}$ Such practices, although untargeted, doubtless did much good. Therapy was largely symptomatic, with stress on ventilation of wards, good food, baths to control fever, and doses of vodka, coffee, and tea as stimulants. ${ }^{29}$

Much of this knowledge was common among ordinary Russians, or at least the educated elite. Ivan Turgenev's widely read 1862 novel Fathers and sons presents a vivid picture of the symptoms of typhus and the terror it caused. One of the protagonists, Evgenii Bazarov, a doctor and prototypical nihilist, acquired typhus by cutting himself while doing an autopsy on a peasant who had died of the disease. Although the fictional mode of infection is improbable, infected lice do leave cold corpses for warm living bodies. Bazarov soon realized that he would die. When the woman he loved visited, he told her to "just sit down over there. ... But don't come near me - the disease is infectious." Although Bazarov died in the summer, when the disease is least prevalent, Turgenev's account is graphic and accurate. Whatever the learned theories about miasmas, Turgenev depicted typhus as transmissable by contact with a victim. ${ }^{30}$

Data for typhus cases in European Russia are available for the years after 1877. These numbers, shown in Figure 5, are obviously incomplete, but do indicate that typhus remained a serious problem throughout the years before World War I. The highest annual total for the period, 184,162 cases in 1892 , with a crude morbidity rate of $15.5 / 100,000$, was associated with a severe famine in the southern and eastern provinces.

Data from individual cities or "gubernias" (provinces) cannot be detailed here, but typhus visited major cities annually in the late nineteenth and early twentieth centuries, and rural people in all provinces were vulnerable to periodic outbreaks. The disease was least common in the far north and the Baltic region, and was especially frequent in Central Russia, the Volga provinces, and parts of the Ukraine. ${ }^{31}$ The map, depicting rates for 50 European gubernias for 1887-1891, indicates the highest morbidity in the central provinces in those years. Although Kostroma and Vladimir gubernias are clearly anomalous, the pattern suggests that provinces with heavy migration to Moscow tended to develop high typhus rates as infected migrants and their lice returned home from winter work in the city. Moscow's economic importance and position at the hub of Russia's railroad network made it an ideal point for disease diffusion.

Serious epidemics took place in the northern Caucasus and southern Russia in 1908, and the central and northwestern gubernias suffered in 1909 and $1910 .{ }^{32}$ An investigation in Voronezh gubernia showed a strong correlation between rural districts with serious food

${ }^{28}$ Kholevinskii, op. cit., note 26 above, pp. 265-8.

${ }^{29}$ Viryuzhskii, op. cit., note 25 above, pp. 105-6.

3) Ivan Turgenev, Fathers and sons, London and New York, Penguin Books, 1982, pp. 191-202 (first published in 1862). The summer occurrence and the confusion of terminology could suggest that the disease was water-borne typhoid fever, but the case is almost certainly typhus.

${ }^{31}$ K. F. Flerov, Sypnoi tif i bor'ba s nim, Moscow, NKZ, 1919, p. 8, presents data for cases in Moscow. There is a good description of a rural epidemic in O. V. Aptekman, 'Epidemiya sypnogo tifa $v$ seleniyakh severnago vrachebnogo uezda', Saratovskii sanitarskii obzor, 1891, pp. 411-26; see also reply by N. K. Lavrentev, 'Po povodu otcheta $O$. A Aptekmana ob sypnogo tifa v Burtsevke', ibid., pp. 493-5. For data by province for 1912-1920, see L. Tarassevitch, 'Epidemics in Russia since 1914: report to the Health Committee of the League of Nations', Epidemiological Intelligence, 1922, 2(5): 36.

32 Vasil'ev and Segal, op. cit., note 7 above, pp. 324-5. 




Average typhus morbidity rates per $100,000,1887-1891$, by guberniya

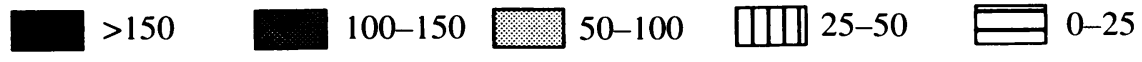




\section{K. David Patterson}

shortages and those with high typhus morbidity. And, typically enough, the city of Voronezh and its prison were major foci. ${ }^{33}$

The extent and behaviour of typhus in the countryside is hard to document. The pattern seems generally to have been endemicity in major cities, with sporadic outbreaks in the relatively isolated villages. Only during major epidemics did typhus sweep over large distances and cause sickness and death over whole provinces and regions. Part of the difficulty in assessing the importance of typhus in rural Russia was the weakness of medical services and the disinclination of peasants to seek treatment from doctors. Reporting was much more complete and accurate in the cities. The disparity between the city of Moscow and the small cities and villages which made up the rest of Moscow gubernia is illustrated in Figure 6. It is not at all clear how much of this disparity is due to problems of reporting and how much reflects the greater incidence of the disease among people dwelling in squalid urban conditions. Both factors probably played a part.

Russian physicians, like their colleagues in Europe, struggled to understand the cause and mode of spread of typhus. They kept up with foreign work and their studies were influenced by, and part of, an international scientific effort. ${ }^{34}$ For example, Ivanov, Golynts, and Orlov used concepts and statistical methods common to contemporary Western writers on urban public health. But the etiology and mode of transmission of the disease remained

Figure 6: Typhus cases in Moscow city and rest of Moscow gubernia, 1892-1908.



City of Moscow Rest of gubernia Total

(Source: V. K., p. 8, see note 48.)

\footnotetext{
${ }^{33}$ M. A. Nevyadomskii, 'Korrespondentsii- o razvitii tifa v Voronezhskoi gub.', Obshchestvennyi vrach, 1909, 4: 156-7.

${ }^{34}$ Charles Murchison's classic text $A$ treatise on the continued fevers of Great Britain, 3rd ed., London, Longman, Greene, 1884 (1 st ed. 1862, 2nd ed. 1873), and other western writers were regularly cited. Hirsch, op. cit., note 3 above, pp. 574-92 has a useful summary of contemporary opinion.
} 
mysterious. Miasmatic views predominated in the early nineteenth century, but growing experience suggested to both Russian and Western physicians that close contact with the sick or their goods was essential for infection. Russian investigators, influenced by the bacteriological revolution of the late nineteenth century, took two major approaches to these problems.

Beginning in 1874, Russian scientists inspired by Otto Obermeier's discovery in the blood of patients of the spirochete which causes louse-borne relapsing fever, began to study the possibility that relapsing fever and typhus might be spread by blood-feeding insects. Their work was preceded by an earlier observation linking lice with typhus. In 1827, Ivan Antonovich Pribil', a military doctor of Czech origin working in the Caucasus, noted that a typhus outbreak among Turkish prisoners and Russian troops had been accompanied by extreme lousiness. He built a "Russian steam bath" to treat the patients, and noted that it killed lice. Systematic use of the bath halted the epidemic; "when there was no more lousiness, there was no more infection". Pribil', however, attributed the success of the bath to the curative powers of steam working through the pores of the skin, and did not see it as a means to kill a vector. ${ }^{35}$ It is not clear whether later investigators were aware of Pribil's work, which was not published until 1841; I have found no nineteenth-century citations of his article.

In 1875, working in Odessa, Grigorii Nicholaevich Minkh inoculated himself with blood from a relapsing fever patient. He fell sick and found Obermeier's spirochete in his blood. He then speculated that both relapsing fever and typhus might be spread by blood-sucking insects such as fleas or bedbugs, and published his ideas in 1878. In 1892 he argued that control of blood-feeding insects was essential to the control of typhus and relapsing fever. ${ }^{36}$ Minkh's associate Osip Osipovich Mochutkovskii, working independently in Odessa, repeated the experiment in March 1876 with blood from a typhus patient, and acquired a case of typhus. He was, however, unable to detect a microbial agent and did not publish his findings until 1900 . He also suspected an insect vector. ${ }^{37}$ Unfortunately, this work, done before Patrick Manson's 1878 report on Culex mosquitoes and filariasis, was not followed up.

There were other attempts to explain the epidemiology of the disease. E. M. Brusilovskii, observing a small epidemic near Odessa, speculated that the disease might spread from farms to residences by means of milk contaminated with old manure. He may have confused typhus with typhoid. ${ }^{38} \mathrm{~A}$. V. Kuznetsov was closer to the truth when he established a chain of cases in a rural epidemic. Kuznetsov speculated that dried respiratory secretions or, more probably, skin peelings from victims stuck to clothes and bedding and conveyed infection. ${ }^{39}$

Most investigators, however, believed that the pathogen was in the blood, and during the early 1890s several Russian scientists attempted to isolate a bacterial agent. In December,

\footnotetext{
${ }^{35}$ Metelkin, in Vasil'ev and Segal, op. cit., note 7 above, pp. 374-6; Vasil'ev and Segal, p. 316. I have not been able to consult the original work.

${ }^{36}$ Metelkin, op. cit., note 14 above, pp. 73-5; Vaindrakh, op. cit., note 8 above, p. 75. I have not yet been able to consult Minkh's original works.

${ }^{37}$ Metelkin, op. cit., note 14 above, pp. 75-6; A. I. Metelkin, 'Russkoe pervenstvo $v$ ustanovlennii roli nasekomykh-rasprostranitelei infektsii', Zhurnal mikrobiologii, epidemiologii, $i$ immunobiologii, 1953, 24(2): 84-5; Vaindrakh, op. cit., note 8 above, p. 68. I have not yet been able to consult the original source.

${ }^{38}$ E. M. Brusilovskii, 'Sluchai vesma veroyatnoi peredachi kontagiya sypnogo tifa cherez posredstvo moloka', Vrach, 1884, no. 2, 20-1.

${ }^{39}$ A. V. Kuznetsov, 'K etiologii sypnogo tifa', Vrach, 1891, no. 12: 308-90.
} 


\section{K. David Patterson}

1891, N. Machinskii, working in Kazan and following earlier work in France and Bohemia, speculated that certain Gram-positive cocci might be the cause of typhus. S. V. Levashov published a series of papers in which he described the latest staining and culture techniques, and animal inoculation experiments to try to link a coccus to typhus. ${ }^{40}$ Similar inconclusive efforts were made with a small bacillus found in typhus skin lesions by $\mathrm{S}$. $\mathrm{M}$. Afanas'ev. ${ }^{41}$ A review by M. G. Benyash in 1899 discussed these and other Russian and foreign efforts to find the typhus germ. All had proved unsuccessful, but Benyash still thought that the coccus might be implicated. ${ }^{42}$ Yet, as Levashov later noted in a 1914 review of the problem, his and other efforts in the past had been stymied by the inadequate bacteriological methods then available. ${ }^{43}$ It is important to note that Russian bacteriologists were working on topics of interest to, and with the latest ideas and techniques of, their Western colleagues. The international quest for a typhus germ, as was the case for many other diseases, turned up many false pathogens. As noted above, the actual rickettsial agent was not found until 1916 and its role was not finally proved for several more years. ${ }^{44}$

Typhus transmission still remained a mystery at the turn of the century, but enough was known to direct at least some useful control measures. Frank Clemow, a British doctor and medical geographer with extensive experience in Russia, summarized current views in 1903. Typhus must be caused by a specific germ, was closely linked with wars and with "ill-nutrition, overcrowding, misery, and insanitation", was most prevalent in winter when people were crowded indoors, and was "probably spread solely by the air or infected fomites. Typhus is one of the most directly infectious of all diseases. The atmosphere around a typhus fever patient appears to contain the infecting agent, whatever this may be, in large quantities and in a high degree of virulence." Infection could only take place over short distances in the air, but it could "attach itself to linen and clothes, the walls of rooms and furniture" and be transported when such items were moved. ${ }^{45}$

The role of the louse as vector was not demonstrated until the work of Charles Nicolle in Tunisia in $1909,{ }^{46}$ but many others must have wondered about the possible role of lice before that. In Odessa, the noted Russian bacteriologist N. F. Gamaleia observed in 1908 that typhus occurred only when lice were present and suggested that they transmitted the

${ }^{40}$ S. V. Levashov, 'O chuzheyadnykh sypnogo tifa', Vrach, 1892, no. 11, pp. 253-4; no. 17, pp. 417-19; 'Sovremennoe sostoyanie voprosa ob etiologii sypnogo tifa', Vrach, 1894, no. 2, pp. 35-6; no. 3, 74-6; 'Noveishiya issledovaniya nad bakteriologiei sypnoi goryachki i nad boleznetvornostyu micrococci exanthematici dlya zhivotnikh', Vrach, 1899, no. 1, pp. 1-4; no. 2, 35-7.

${ }^{41}$ S. M. Afanas'ev, 'Bakteriologicheskaya issledovaniya sypnogo tifa', Vrach, 1895, no. 36, pp. 1000-3.

${ }^{42}$ M. G. Benyash, 'K bakteriologii sypnogo tifa', Vrach, 1899, no. 44, pp. 1287-8; no. 45, pp. 1321-5.

${ }^{43}$ S. V. Levashov, 'O chuzheyadnikh sypngo tifa', Vrach, 1914, 13(1), pp. 109-10.

${ }^{44}$ Victoria A. Harden, 'Koch's postulates and the etiology of rickettsial diseases', J. Hist. Med. allied Sci., 1987, 42: 277-95. Muriel Robertson's review, 'Recent researches into the etiology of typhus', Proc. R. Soc. Med., 1917,10 (part 2): 95-110, and accompanying comments (pp. 111-18) provide a good contemporary summary of the debate in Britain. One commentator claimed to have suspected the role of lice as early as 1901. In retrospect, it seems puzzling that there had not been more speculation about louse transmission.

${ }^{45}$ Frank G. Clemow, The geography of disease, Cambridge University Press, 1903, pp. 503-8, Clemow worked for many years at a hospital for British sailors at Kronstadt, near St Petersburg, and knew many leading Russian physicians and officials. A very similar account of typhus etiology and epidemiology is given in an influential German work by H. Curschmann, Typhoid fever and typhus fever. I have consulted the 1902 English translation, edited by William Osler, Philadelphia and London, W. B. Saunders, pp. 475-90.

${ }^{4}$ Nicolle's work and studies leading up to it are described in Félix Regnault, 'Historique de la découverte du rôle du pou comme agent de transmission du typhus', Revue moderne de médecine et chirurgie, 1928, 12: 366-70. 
disease between people. ${ }^{47}$ The climate of scientific opinion was certainly favourable for the acceptance of Nicolle's discovery in Russia and elsewhere. ${ }^{48}$ Gamaleia and many others quickly began to develop practical delousing methods and their techniques were put to good use in the next several years.

During World War I, typhus was contained by both sides in the West, but it was a scourge all along the Eastern front, causing some 150,000 deaths in Serbia in 1915, and becoming common among Russian and Romanian troops and their adversaries. ${ }^{49}$ Russian troops fighting the Turks in the Caucasus also suffered from typhus. ${ }^{50}$ Morbidity rates in the army rose from a peacetime figure of $0.13 / 1,000$ in 1913 to $2.33 / 1,000$ in $1915 .^{51}$ German authorities had to deal with typhus among Russian prisoners of war from late $1914 .^{52}$ The epidemic developed slowly, however, and for many months control measures, mostly administered by doctors from the zemstvos and urban public health departments and by the Red Cross, not by the military or the floundering Czarist government, seemed effective. ${ }^{53}$ Soldiers, refugees, and prisoners brought typhus infection into the interior as far as western Siberia, especially after the defeats in Poland in late $1915,{ }^{54}$ but, as Figure 5 shows, civilian cases remained surprisingly low until 1918. There was a small epidemic in western Kazakhstan in 1915, with 1,129 cases and 115 deaths. ${ }^{55}$ In Moscow, the number of cases rose from 245 in 1914 and 251 in 1915, to 916 and 1,095 in the next two years, and reached the alarming figure of 6,988 in $1918 .{ }^{56}$ Petrograd, the newly rechristened capital, recorded 517 cases in 1917 and 10,976 in $1918 .^{57}$ The early months of 1918 also saw a flare up in Lithuania. ${ }^{58}$ In the harsh winter of $1917-18$, at the very dawn of Soviet power, the greatest typhus epidemic in history was beginning in war-torn, destitute Russia.

Typhus was able to spread with unprecedented rapidity in the desperate conditions of Russia during 1918-1922, and the disease had a substantial impact on military activities and on the fate of the Bolshevik revolution and the White counter-revolution. Beginning in the cities and the central provinces, epidemic typhus spread beyond the Urals to Siberia and Central Asia by late 1919, and engulfed the entire country during 1920. After a brief lull during most of 1921 as the Civil War ended, typhus returned again with famine, causing special havoc in the Ukraine and the Volga provinces in $1922 .{ }^{59}$

${ }^{47}$ Bolshaya Sovetskaya Entsyklopedịa, Leningrad, Gosudarstrennoe Nauchnoe Izdatel'stvo, 1952, vol. 10, pp. 182-3; 1955, vol. 3i, p. 939.

+4 "V. K." in Obshchestvennivi vrach, 1911, no. 1, pp. 1-8.

49) Jean Laussel, 'L'évolution du typhus exanthématique en Europe depuis 1914', thesis for Doctorat en Médecine, University of Paris, 1928, pp. 14-24.

so) Flerov, op. cit., note 31 above, p. 8.

${ }^{51}$ M. D. Kovrigina (ed.), Sorok let sovetskogo zdravookhraneniya, Moscow, Medgiz, 1957, p. 313.

52 Paul Weindling, 'Medicine and the Holocaust: the case of typhus', in I. Löwy, A. Moulin, and P. Pinel (eds), Medical innovation, London and Paris, J. Libbey, in press, pp. 405-7. I am grateful to Dr Weindling for giving me a copy of this paper.

${ }_{53}$ John F. Hutchinson, Politics and public health in revolutionar. Russia, 1890-1918, Baltimore, Johns Hopkins University Press, 1990, pp. 117-25; William E. Gleason, 'The All-Russian Union of Towns and the politics of urban reform in Tsarist Russia', Russian Review, 1976, 35(3): 280-302.

${ }^{54}$ E. I. Lotova and Kh. I. Idel'chik, Bor'ba s infektsionnymi boleznyami v SSSR (1917-1967), Moscow, Meditsina, 1967, pp. 32-59.

${ }^{55} \mathrm{~S}$. Kh. Dushmanov, 'Zemskaya meditsina v zapadnom Kazakhstane', Sovetskoe -dravookhranenie, 1987, 4: $68-71$, on p. 71 .

${ }^{56}$ Flerov, op. cit., note 31 above, p. 8.

57 Tarassevitch, op. cit., note 31 above, p. 36.

${ }^{58}$ Laussel, op. cit., note 49 above, pp. 20-1.

${ }^{59}$ V.S. Solov'ev, 'Epidemii v SSSR za 10 let posle Oktyabrya', Gigiena i epidemiologiva, 1927, 6( 10): 37-41, on p. 38 . 


\section{K. David Patterson}

Masses of civilian refugees and demobilized or deserting soldiers swamped the railways, roads, and rivers of Russia, fleeing the armies of the Central Powers until the end of World War I, then seeking safety from Reds, Whites, Ukrainian and other nationalist formations, Allied interventionists, Polish invaders, anarchists, peasant rebels, and bandits. Extensive troop movements, often conducted over large distances by ill-disciplined soldiers, spread violence and disease. War, brutal Communist food requisitioning policies, the depredations of other contenders for power, and general economic collapse discouraged agricultural production. Food and fuel shortages forced millions of urban people to flee the hungry, freezing cities. Rural food shortages, culminating in famine in 1921, afflicted vast regions and generated massive flows of destitute fugitives. Lice and typhus flourished in the midst of this massive misery. They also followed the Polish army's retreat from the Ukraine in 1920, causing a major epidemic in that new republic. ${ }^{60}$

All sources agree that the railways, jammed with destitute people frantically fleeing urban collapse, rural hunger or the fighting, played a major role in the dissemination of typhus. Crowding, chaos, a partial collapse of medical and public health services, wretched sanitary conditions, and a critical shortage of soap and fuel contributed to the general lousiness of the population and the resulting epidemic.

In the south, typhus appeared in the autumn of 1918 among the Red 11 th Army operating in the northern Caucasus, and quickly spread to its White adversaries. The Whites suffered almost as many typhus deaths as military ones during the next several months and an important White leader, General P. N. Wrangel, almost died of it. But, with access to foreign medical supplies, they fared better than the Reds. ${ }^{61}$ The Red force suffered about 50,000 cases of typhus and, largely because of this, lost control of the key Terek region. ${ }^{62}$ Over 29,000 11 th Army victims were evacuated to Astrakhan where, despite efforts to isolate the sick soldiers, the disease spread to the civilian population. Here, as elsewhere, doctors and medical workers suffered very high morbidity and mortality rates. ${ }^{63}$ Typhus swept the Ukraine and southern Russia during the fighting in 1919 and early 1920, advancing and retreating with the "regular" Red and White forces, the irregular units of various Ukrainian "governments", the anarchist bands of Nestor Makhno, and waves of refugees. The White retreat during the winter of 1919-20 was hampered by the tens of thousands of typhus sufferers who overwhelmed makeshift hospitals. Fortunately for the Whites, the Red Army's attempts to pursue them were severely hampered by a major typhus outbreak in their own ranks. ${ }^{64}$ By mid-December some 1.5 million refugees had fled south from the advancing Reds to Rostov-on-Don, where thousands perished from typhus. ${ }^{65}$

(1) Alfred E. Cornebise, Typhus and doughboys: the American Polish typhus relief expedition, 1919-1921, East Brunswick, Associated Universities Presses, 1982; Gaines M. Foster, 'Typhus disaster in the wake of war: the American-Polish relief expedition, 1919-1920', Bull. Hist. Med., 1981, 54: 221-32.

${ }^{61}$ Peter Kenez, Civil war in south Russia, 1918: the first year of the Volunteer Army, Berkeley, University of California Press, 1971, p. 189; idem., Civil war in south Russia, 1919-1920: the defeat of the Whites, Berkeley, University of California Press, 1977, p. 23.

${ }^{62}$ Kenez, Defeat of the Whites, op. cit., note 61 above, p. 29; Evan Mawdsley, The Russian civil war, Boston, Unwin Hyman, 1987, pp. 161-3.

${ }_{6.3}^{3}$ N. S. Trizno, 'Bor'ba s tifami v nizhov'yakh Volgi v gody grazhdanskoi voiny', Zhurnal mikrobiologii, epidemiologii i immunobiologii, 1973, 50: 147-50.

it J. M. Mitchell, I. N. Asheshov, and G. P. N. Richardson, Typhus fever, with special reference to the Russian epidemics, London, Ballière, Tindall and Cox, 1922, pp. 9-14; Kenez, Defeat of the Whites, op. cit., note 61 above, p. 222.

${ }^{65}$ Kenez, Defeat of the Whites, op. cit., note 61 above, p. 225. 
A British officer described the situation in Rostov around Christmas 1919. "There was no fuel to thaw water or heat it for a bath, or to wash clothes in; waterpipes had frozen and burst; few people possessed spare shirts or underclothes; and as for avoiding crowds, you could not move a step without running the risk of infection. The railway stations and the trains were the worst typhus traps. Crowds of passengers and soldiers camped in the waiting rooms and public halls. The bitter weather made them keep the windows shut, and the filth, the overcrowding, and the stinking atmosphere bred lice to perfection. Besides this, the habit of living in trains had grown. Everybody who could took a railway coach to live in", thus gaining both mobility and a place to live. ${ }^{66}$ The officer's description applied to many other places in Russia during the typhus years.

Other fronts suffered as well. In the East, Admiral Kolchak's White forces and the 3rd Red Army which faced them were ravaged by typhus during the autumn of 1919. Red reinforcements coming by rail from the west infected the civilian population of the city and province of Perm, despite measures to isolate victims and delouse persons and clothing in steam baths. ${ }^{67}$ The Whites suffered even more heavily and fresh Red troops contracted typhus from the retreating Whites. ${ }^{68}$ Typhus swept the Urals and followed the armies into western Siberia. Sick White troops infected Omsk in August 1919, and Red prisoners shipped eastward brought typhus to Irkutsk in September. During the desperate White retreat in late 1919 and early 1920, mobs of refugees and demoralized soldiers infected Tomsk and other Siberian cities and spread typhus along the entire line of railway to Irkutsk and beyond Lake Baikal to the Pacific. ${ }^{69}$ By early 1920 an estimated 50,000 Kolchak soldiers had died of typhus. ${ }^{70}$

Typhus was also a factor on the smaller Arctic and Baltic fronts. White troops and the civilians of Archangel were said to have been infected by Red prisoners crowded into a filthy jail. ${ }^{71}$ In the north-west, typhus followed the defeated White forces of General Yudenich's army into Estonia in November 1919. ${ }^{72}$ Thousands of sick soldiers were confined in rudimentary hospitals under grim conditions. Red Cross units led by American officers directed the Estonians and the remaining Russian commanders in cleaning up these buildings and their inmates, whose clothing and blankets seemed "alive" with masses of lice. Teams of 50 men, equipped with masks, protective clothes, and gloves, shaved and bathed the patients, burned mattresses, sterilized clothes, and disinfected wards with carbolic acid. ${ }^{73}$ The newly independent Estonians began to quarantine their borders with the aid of American Red Cross workers and brought the epidemic there under control. ${ }^{74}$

${ }^{66}$ Carl E. B. Roberts, In Denikin's Russia and the Caucasus, 1919-1920, London, W. Collins, 1921, p. 169.

${ }^{67} \mathrm{~V}$. T. Selezneva, 'Iz istorii bor'by s parazitarnymi tifami $v 3$-i armii vostochnogo fronta $v$ gody grazhdanskoi voiny', Sovetskoe zdravookhranenie, 1964, 23: 39-43.

${ }^{68} \mathrm{Yu}$. A. Polyakov, Sovetskaya strana posle okonchaniya grazhdanskoi voiny, Leningrad, Nauka, 1986, p. 114.

${ }^{69}$ George Stewart, The White armies of Russia: a chronicle of counter-revolution and allied intervention, New York, Russell \& Russell, 1933, pp. 300, 323; Georges Montaudon, 'Le typhus exanthématique en Sibérie', La vie médicale, 1921, 2: 1439-40.

${ }^{70}$ Boris Urlanis, Wars and population, Moscow, Progress, 1971, p. 164.

${ }^{71}$ Leonid I. Strakhovsky, Intervention at Archangel: the story of allied intervention and Russian counterrevolution in north Russia, New York, Howard Fertig, 1971, p. 156.

${ }^{72} \mathrm{~W}$. Bruce Lincoln, Red victory: a history of the Russian civil war, New York, Simon \& Schuster, 1989, p. 300 .

${ }^{73}$ Lt. Col. Edward W. Ryan to Lt. Col. Robert E. Olds, 27 February 1920, National Archives of the United States, R.G. 200, Red Cross, R.G.2, 894.9, Estonia, leaves 1-5.

${ }^{74}$ Ryan to Olds, 25 May 1920, Ibid. 


\section{K. David Patterson}

Typhus did not cause either side to win or lose the Civil War. Although it influenced various campaigns and may well have fatally damaged Kolchak's forces, the disease ravaged both sides on all fronts. There are no accurate figures for military morbidity or mortality, but a Soviet demographer has estimated that there were at least 573,000 typhus cases resulting in some 100,000 deaths in the Red Army from 1918 to 1920 . Official reports gave typhus morbidity rates as high as 204 per 1,000 in 1919 and 315 per 1,000 in $1920 .^{75}$ Overall White losses remain unknown. ${ }^{76}$

The 1918-1922 typhus epidemic was unprecedented in the history of the disease. Figure 5 speaks for itself; the graph must be on a logarithmic scale to capture the enormous number of officially recorded cases. Official returns show that typhus conformed to its usual seasonal pattern. Indeed, as indicated in Figure 7, the monthly distribution of cases throughout 1918-1920 was even more heavily biased toward the winter months than during the pre-war years. The total of some 7 million cases reported to the League of Nations Health Organization, and published in their reports and elsewhere, ${ }^{77}$ greatly underestimates the real toll. These numbers reflect very incomplete returns. Two widely quoted contemporary observers, A. N. Sysin and L. A. Tarassevich, respectively estimated the total number of cases as being from between 15 and 16 million to 25 million. ${ }^{78}$ Data for individual provinces for 1918-1921 suggest that the most complete reporting was from central Russia, the northern Urals, and the northern Volga provinces. ${ }^{79}$ There are no reports at all from the hard-hit Ukraine for 1918 and 1919, and Ukrainian data for later years are very incomplete. Large areas of the Ukraine, Belorussia, and parts of western Russia were occupied by the Central Powers in 1918, so the Soviet authorities had no information on events there. Similarly, from 1918 to 1922 extensive territories were controlled by counter-revolutionary forces or by the invading Poles. Neither the Poles nor the various weak and short-lived "White" governments seem to have made much of an effort to assess typhus cases or deaths. Even the regions remaining under Soviet control suffered from brigandage, local revolts, and the extreme hardships of War Communism, making reporting difficult. The last years of the epidemic were marked by widespread famine, further complicating the gathering of information. The hard-pressed medical staffs of the contending armies were not able to keep accurate counts of their sick and dead soldiers, let alone of civilians.

There are three ways to approach the question of the true magnitude of the epidemic and its toll. One, which will not be pursued here, would be to attempt to pull together a coherent picture from scattered medical writings, official reports, personal accounts, the impressions of travellers, and descriptions of the Civil War. Suffice it to say that, taken together, even a small sampling of the available sources paints a truly horrible picture of the scale of suffering. It is clear that typhus struck the entire country, rural and urban, from the Caucasus

\footnotetext{
${ }^{75}$ Lotova and Idel'chik, op. cit., note 54 above, p. 112.

${ }^{76}$ Urlanis, op. cit., note 70 above, pp. 161-4.

${ }^{77}$ League of Nations, Annual epidemiological reports; see also Laussel, op. cit., note 49 above, p. 36; Tarassevitch, op. cit., note 31 above, p. 45.

${ }^{78}$ A. Sysin, 'Epidemii v Rossii v 1914-22 godakh', Vrachebnaya gazeta, 1927, nos. 10-11, pp. 265-9; L. A. Tarassevich, 'Epidemii poslednikh let v Rossii', Obshchestvennyi vrach, 1922, no. 1, pp. 43-50; Lotova and Idel'chik, op. cit., note 54 above, p. 66.

${ }^{79}$ D. D. Pletnev, Sypnoi tif, 2nd ed., Moscow, Knizhnaya pomoshch', 1922, pp. 16-21.
} 
Figure 7: Typhus seasonality 1912-14 and 1918-20, percentage of all cases by month.
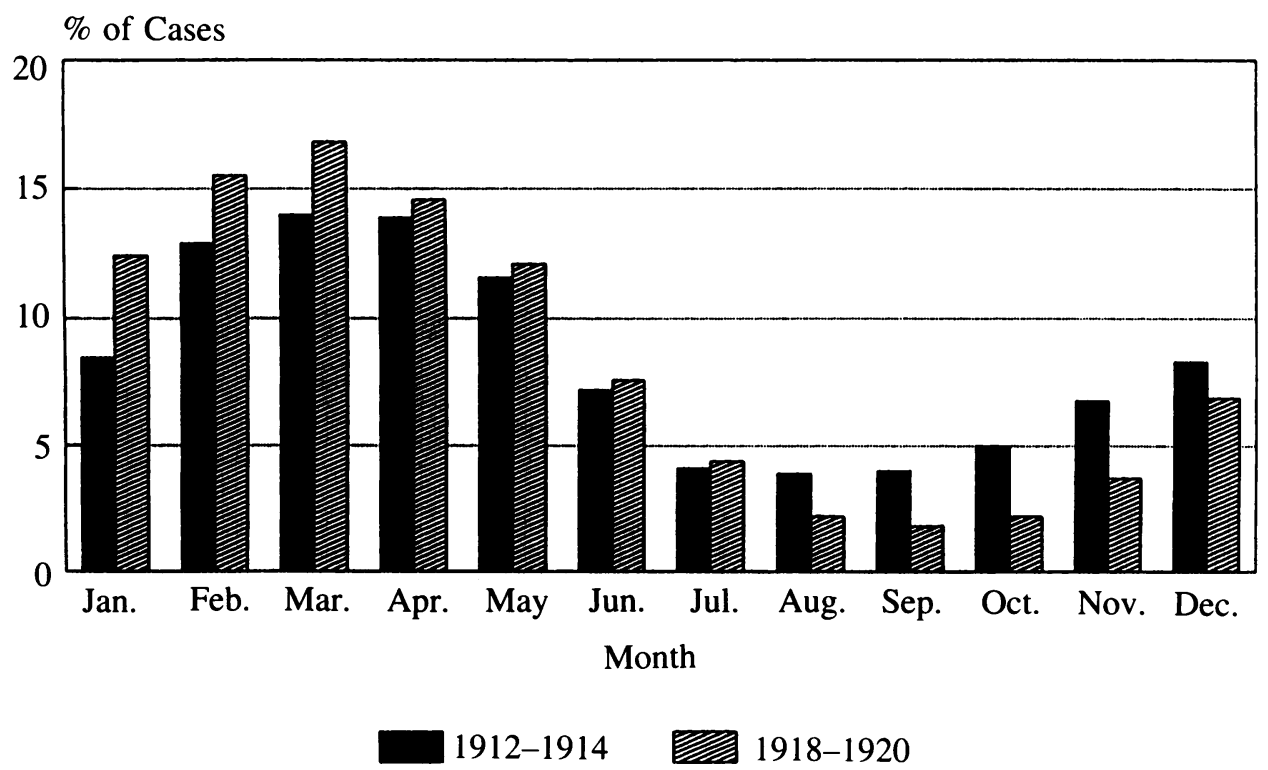

(Source: calculated from Pletnev, pp. 23-4, see note 79.)

to the Arctic and from the Baltic to the Pacific. The epidemic seems to have been worst in central and northeastern European Russia, the northern Caucasus, the Volga provinces, western Siberia, and parts of the Ukraine, the areas which saw the heaviest fighting and the most extensive troop and refugee movements. The mid-Volga province of Saratov, whose typhus rate exceeded the national average before and during World War I, suffered disproportionately during the great epidemic. ${ }^{80}$ The devastating impact of typhus on the city of Saratov is illustrated in Figure 8.

Two special studies provide a basis for a more quantitative estimate of morbidity and mortality. In 1922 the eminent physician L. A. Tarassevich presented to the League a report on the epidemic from 1918 to 1921; his figures have been quoted by many later observers. ${ }^{81}$ Tarassevich tried three approaches to derive more accurate estimates from the very incomplete official returns of just under 6.9 million cases. First, he sent questionnaires to doctors around the country seeking their estimates of typhus cases and deaths and seeing how these corresponded to official data. Second, he attempted to evaluate official returns against the availability of health care centres, with corrections for regions beyond government control. Third, he extrapolated rates fom cities and provinces which seemed to have the best data to other regions, making various qualifications depending on local circumstances. All three methods produced estimates falling within the range of 20 to 30 million cases; his best guess was 25 to 30 million, or about 20 to 25 per cent of the population. ${ }^{82}$ Allowing for a conservative average case mortality rate of 10 per cent, this

${ }^{80} \mathrm{~S}$. G. Wheatcroft, 'Famine and epidemic crises in Russia, 1918-1922: the case of Saratov', Annales de démographie historique, 1983, pp. 329-52, on p. 349.

81 Tarassevich, op. cit., note 31 above; see also Tarassevich, op. cit., note 78 above.

${ }^{82}$ Tarassevich, op. cit., note 78 above, pp. 43-48; Tarassevich, op. cit., note 31 above, pp. 17, 19. 


\section{K. David Patterson}

Figure 8: Typhus death rates/10,000 and percentage of deaths with cause, city of Saratov, 1918-1924.

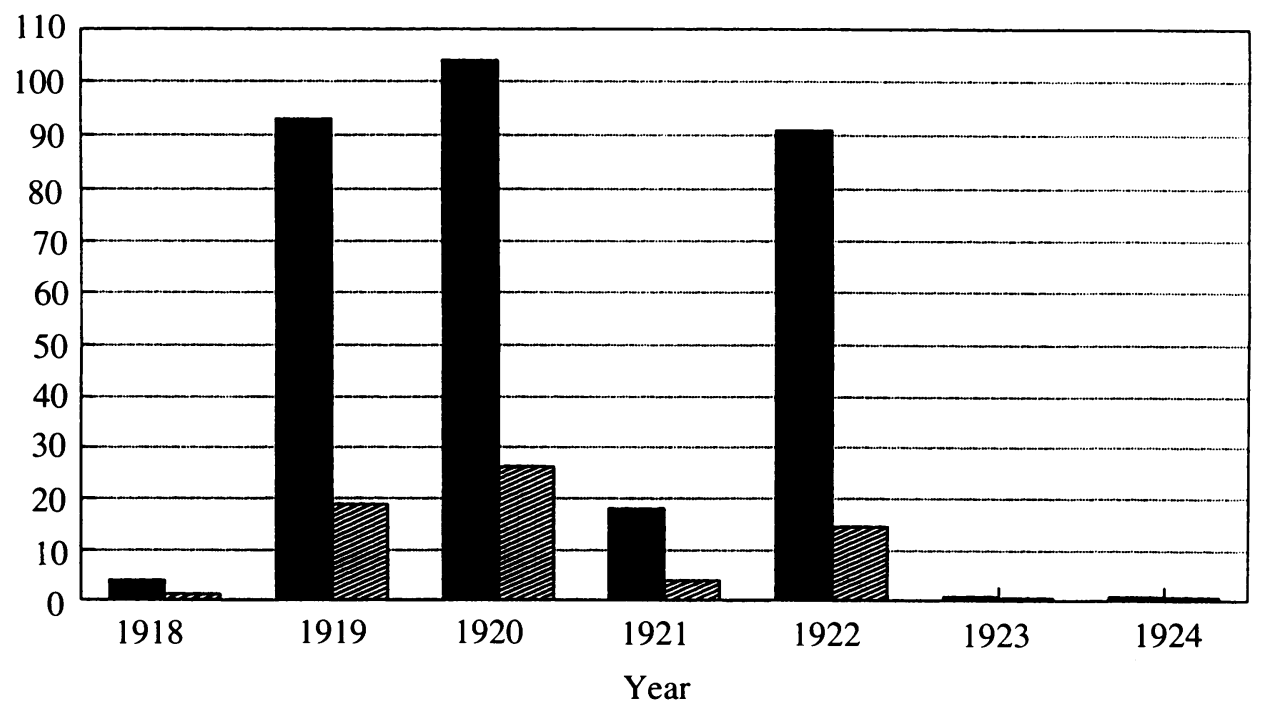

Deaths $/ 10,000$ with known cause

(Source: Wheatcroft, p. 339, see note 80 .)

would indicate some 2.5 million deaths from typhus in the years 1918-1921. The official case total for 1922 was about 1.5 million, indicating that Tarassevich's higher morbidity and mortality estimates might be more plausible for the entire epidemic.

A second study which sheds light on the official returns is a remarkable survey done on the entire populations of a two per cent sample of all Ukrainian villages in 1923 by the Ukrainian government and the Ministry of Health (Narkomzdrav). The survey covered all nine Ukrainian provinces. Residents were questioned about sicknesses, deaths, and war casualties for the period 1920-1922, and socio-economic data were compiled on each villager and village. Data were compared to the obviously incomplete registration of morbidity and mortality by village and by province. Gross under-registration of cases was evident; the average real number of cases for the three years and nine provinces was 4.2 times greater than the 1.15 million reported. Thus the total number of cases estimated for the whole Ukraine was over 4.8 million and, based on the 13.6 per cent case-mortality rate reported by survivors, there were some 560,000 typhus deaths between 1920 and 1922 . The survey takers determined that typhus morbidity and mortality had also been significant in 1918 and 1919, but decided that problems of recall precluded accurate estimates. ${ }^{83}$ The survey totals are supported by an estimate by Dr Kholodny of the International Red Cross. Kholodny believed that the official morbidity figures were at least $2 \frac{1}{2}$ times too low and

\footnotetext{
${ }^{8.3}$ Ukraine, Tsentral'noe Statisticheskoe Upravlenie, i Narodnyi Kommisariat Zdravookhraneniya, Materialy o sotsial'no-gigienicheskom sostoyanii ukrainskoi derevni, Khar'kov, 1924, pp. 1-43, especially pp. 2-7, 20-2, 24-32.
} 
that case mortality was 9 to 10 per cent in the cities and higher in the countryside. ${ }^{84}$ Although the exact total is unknown, it is clear that approximately 20 per cent of the Ukrainian population had contracted typhus between 1920 and $1922 .^{85}$

Despite the new knowledge about the role of lice, those attempting to control the epidemic and treat its victims suffered greatly. Petrograd's physicians died of typhus at about six times the rate of the general population. ${ }^{86}$ In some hospitals and evacuation centres, as in Kharkov in 1920, all doctors, nurses, orderlies, and disinfection personnel contracted typhus. In 1919-20, 4,000 public health physicians got the disease and 800 (20 per cent) died. From 1918 to $1920,1,183$ of 3,500 Red Army doctors got typhus and 235 of these (19.9 per cent) died. Praise for the heroism of medical personnel was well deserved. ${ }^{87}$

Obviously, none of the methods described above can give a precise indication of the toll taken by typhus between 1918 and 1922. It is worth noting that Tarassevich's estimates have been accepted as reasonable by most later writers and his figures seem to reflect the, admittedly impressionistic, literary evidence. Another contemporary Red Cross observer, Dr Ferrière, believed that about 20 to 25 per cent of the whole population had been infected and, using a case mortality rate in the range of 10 to 12 per cent, suggested a death toll of some 2.5 million. ${ }^{88}$ The estimates derived from the Ukrainian village surveys are in general accord with Tarassevich's opinion of the situation there. Including 1922, typhus deaths may well have reached 3 million. Foreign invasion, civil war, economic collapse, famine, and concomitant diseases like cholera, the influenza pandemic of 1918-19, and the greatest epidemic of louse-borne relapsing fever ever recorded, all compounded the misery of the Soviet population and made combating typhus much more difficult. The impact of typhus and other infectious diseases on Russia's dramatic demographic losses between 1914 and 1922 requires much further research. Changes in archival policy and the publication of the results of the previously suppressed 1937 census should make this feasible.

Civilian and military authorities and most of the public were fully aware of the role of lice in the transmission of typhus, and louse control was the major public tool. Despite frantic research efforts from 1918 to 1920, there was no effective vaccine. Digitalis, quinine, and other drugs were sometimes tried, but in the absence of specific therapy, rest and symptomatic treatment were all that was available. No cure was more effective than good nursing and supportive care, neither of which could be easily provided at the time. ${ }^{89}$

The seriousness of the epidemic and the role of lice was graphically illustrated by V. I. Lenin's often cited 1919 remark, "All attention to this problem, comrades. Either lice will conquer socialism, or socialism will conquer lice."90 Both Soviet and White authorities

\footnotetext{
${ }^{84}$ Kholodny, 'La situation sanitaire de l'Ukraine', Revue internationale de la Croix Rouge, 15 April 1922, 53(4): 284-90, on pp. 286-8.

85 Op. cit., note 83 above, p. 43.

${ }^{86}$ Christopher Williams, 'War, revolution and medicine: the case of the Petrograd doctors, 1917-20', Revolutionary Russia, 1991, 4(2): 259-87, pp. 266-7.

${ }^{87}$ Lotova and Idel'chik, op. cit., note 54 above, p. 191.

${ }^{88}$ Frédéric Ferrière, 'Situation épidémique de la Russie', Revue internationale de la Croix Rouge, 15 April 1922, 53(4): pp. 273-83, on p. 277.

${ }^{89}$ H. M. Davison, 'Typhus in Siberia-observations upon myself and others', J. med. Assoc. Ga, 1921-22, 11: 258-63, on p. 262; Lotova and Idel'chik, op. cit., note 54 above, pp. 186-7.

${ }^{90}$ Cited in K. K. Vasil'ev, 'Rol' pervykh vserossiskikh s"ezdov bacteriologov i epidemiologov $v$ bor'be $s$ epidemiyami parazitarnykh tifov', Zhurnal mikrobiologii, epidemiologii, $i$ immunobiologii, April 1981, pp. 106-7. I have not yet been able to consult the actual proceedings of this meeting.
} 


\section{K. David Patterson}

publicized the importance of louse control. That such educational efforts succeeded is suggested by the experience of the noted sociologist P. A. Sorokin. Jailed in grim conditions by the Reds in 1918, Sorokin feared lice, but noted that some condemned prisoners attempted to shorten their misery by staying close to sick cell-mates and even putting lice from the dying onto their own bodies. ${ }^{91}$ Another academic, the historian Yu. V. Got'e, pleased by the unusual experience of travelling on an apparently louse-free train, reported that he "neither saw nor felt any lice, or 'semashkos' as they now call them". Got'e revealed his political sentiments by using the name of N. A. Semashko, Bolshevik Commissar for Health, to refer to vermin. ${ }^{92}$

The basic strategies used to combat lice in this pre-DDT era were outlined by Dr K. F. Flerov in early 1919. These methods, isolation of patients and disinfection of their clothes and rooms, were similar to those for typhus and other diseases in the late nineteenth and early twentieth centuries, but knowledge of the role of lice gave them a focus. Patients were to be moved to clean hospitals and deloused before admission. Hairy areas of the body were to be shaved and treated with kerosene or benzene. Patients should be confined to the hospital for 5 to 15 days after recovery to prevent them infecting more lice. Victims' residences and possessions were to be disinfected with steam, dry heat, or benzene fumes and their families and friends closely observed for signs of illness. Sulphur and carbolic acid were also acceptable disinfectants; hydrogen cyanide was effective but very dangerous. ${ }^{93}$ Steam disinfection of clothes, linens, and people was widely employed by both Whites and Reds. ${ }^{94}$

Public health and military authorities tried to keep infected populations away from vulnerable areas but with little success. Extensive efforts were made to educate the public by pamphlets and lectures; railway carriages with special exhibits toured the areas under Soviet control. Officials attempted to control railway passengers and on 6 December 1919 proclaimed a week of cleaning railway stations. ${ }^{95}$ Special attention to the railways was an essential feature of the anti-typhus campaign. By November 1919, for example, disinfection teams were treating 40-50,000 passengers daily in Moscow train stations. Eventually, the Soviet government set up some 250,000 beds for typhus patients and erected about 300 isolation and disinfection stations along the railways and waterways. Hundreds of bathing and disinfection detachments were created in the military to delouse the troops. The Russian Red Cross also provided similar facilities. ${ }^{96}$

Delousing did exterminate masses of lice; a two inch layer of dead lice covered the floor of one Red Army disinfection room. ${ }^{97}$ Delousing, isolation, and education no doubt contributed to the ultimate abatement of the epidemic, as did the rapidly growing numbers

${ }^{91}$ Pitirim A. Sorokin, Leaves from a Russian diary-and thirty years after, Boston, Beacon, 1950, p. 198.

${ }^{92}$ Terence Emmons (ed.), Time of troubles: the diary of lurii Vladimirovich Got' $e$, Princeton University Press, 1988 , p. 333.

${ }^{93}$ Flerov, op. cit., note 31 above, p. 17-18, 44-50. Flerov's work presents an excellent view of the contemporary understanding of typhus and its epidemiology. Similar information is given by A. N. Sysin, Sypnoi tif $i$ bor'ba c nim, Moscow, NKZ, 1919, pp. 1-31.

${ }^{94}$ Harry M. Gellert, 'Some aspects of typhus fever in Transcaucasia, especially with regard to protective measures against lice-borne disease', J. R. Nav. med. Serv., October 1920, 6: 394-8; Lotova and Idel'chik, op. cit., note 54 above, p. 104.

95 V. Z. Drobizhev, U istokov sovetskoi demografii, Moscow, Mysl', 1987, pp. 86-8; Vasil'ev, op. cit., note 90 above, p. 108.

${ }^{96}$ Kovrigina, op. cit., note 51 above, p. 44, pp. 320-1, p. 606.

${ }^{97}$ Lincoln, op. cit., note 72 above, p. 64. 


\section{Typhus and its control in Russia, 1870-1940}

of survivors who had acquired immunity, but the real reason that typhus declined was the return of a degree of normality. The civil war and the conflict with Poland ended in 1920 and, despite continuing unrest in many rural areas, peace meant less destitution and fewer refugees and soldiers on the move. Much of the Ukraine was swept by famine, but conditions there improved by late 1922 . No longer sustained by human misery and mobility and under persistent attack by health authorities, typhus declined markedly after 1922 .

Reported typhus cases, no doubt counted more completely with the return of settled conditions, fell steadily until 1931 . There was a sharp rise from 17,828 officially recorded cases in that year to 78,132 in 1932, a fall to 35,218 in 1933, and another increase to 56,194 in 1934. Cases remained in this range through 1937, when the USSR ceased reporting morbidity and mortality statistics to the League of Nations Health Organization. These increases, and rising rates for several infectious diseases in the early 1930s, reflect declining health conditions caused by Stalin's intensive industrialization drive and the disastrous collectivization campaign in the countryside. It is highly probable that the real toll was much higher than the figures sent to the League. Graphs (but not tables) of typhus cases and deaths from 1913 to 1967 have been published by Baroyan. His data, shown by bars in Figure 5, indicate some 200,000 cases in 1932, over 800,000 in 1933, and more than 400,000 in $1934 .^{98}$ Clearly, the role of infectious diseases during the harsh circumstances of the "Stalin Revolution" requires further examination.

Another Soviet institution, greatly expanded under Stalin in the 1930s, provided a fertile arena for infectious diseases, especially typhus. The labour camps of the gulag imprisoned millions who sickened and died without published record. Lice were ubiquitous in the camps, despite the nominal existence of disinfection stations and bathing facilities. Shalamov's essay 'In the bathhouse' gives a graphic description of delousing from a prisoner's perspective. ${ }^{99}$ Typhus reportedly killed tens of thousands of inmates in one camp in the Kolyma district in $1938 .{ }^{100}$ Millions died in the gulag; the contribution of typhus to the toll may have been small compared to hunger, cold, exhaustion, and murder, but it was probably considerable.

Even Baroyan's pessimistic data make one major fact clear; despite the devastation of World War II, Soviet authorities were able to contain typhus to a remarkable degree during that conflict. There was a substantial increase during the war years, but the numbers of cases never approached those recorded in the post-revolutionary period. ${ }^{101}$ There were, however, numerous cases in besieged Leningrad. ${ }^{102}$ Beginning in 1973 doctors in the former capital recorded several hundred cases of Brill's disease, flare-ups of old typhus infections among older people who had survived the war. ${ }^{103}$

Typhus cases in the USSR declined from 1,100 in 1980 to 500 in 1985 and 300 in $1989 .^{104}$ A continuation of this trend will mark the end of typhus as a scourge of the lands of Russia and the former Soviet Union, unless something like the horrible conditions of 1918-1922 should reoccur.

\footnotetext{
${ }^{98} \mathrm{O}$. V. Baroyan, Itogi poluvekoi bor'by $\mathrm{s}$ infektsiyami v SSSR i nekotorye aktual'nye voprosy sovremennoi epidemiologii, Moscow, Meditsina, 1968, p. 56.

${ }^{99}$ Varlam Shalamov, 'In the bathhouse', in his Kolyma tales, New York, W. W. Norton, 1982, pp. 39-45.

${ }^{100}$ Robert Conquest, Kolyma: the Arctic deathcamps, New York, Viking, 1978, pp. 22, 136-140.

${ }^{101}$ Borayan, op. cit., note 98 above, p. 34.

${ }^{102}$ Harrison E. Salisbury, The 900 days: the siege of Leningrad, New York, Da Capo, 1985, pp. 492, 507.

${ }^{103}$ A. B. Daiter, N. K. Tokarevich, et al., 'Sypnotifoznaya infecktsiya (Bolez' Brilla) v usloviyakh krupnogo goroda', Zhurnal mikrobiologii, epidemiologii, i immunobiologii, 1989, 6: 43-7.

104 'Zabolevaemost' naseleniya', Vestnik statistiki, 1990, 12: 51.
} 